\title{
Jihad: Warfare and Territorial Expansion in Islam
}

\author{
Etim E. Okon ${ }^{1}$ \\ ${ }^{1}$ Department of Religious and Cultural Studies, University of Calabar, Nigeria \\ Correspondence: Etim E. Okon, Department of Religious and Cultural Studies, University of Calabar, C/O G. P. \\ O BOX 2897 Calabar, CRS, Nigeria. Tel: 234-80-3802-5231. E-mail: dretimokon55@gmail.com
}

Received: January 11, 2013 Accepted: February 28, 2013 Online Published: April 27, 2013

doi:10.5539/ass.v9n5p171

URL: http://dx.doi.org/10.5539/ass.v9n5p171

\begin{abstract}
This paper examines the concept of jihad in Islamic tradition and theology, the study unveils the logical and hermeneutical presuppositions of Islam in upholding the doctrine of jihad in the $21^{\text {st }}$ century. As a universalistic religion with the ultimate aim of converting the entire world and eliminating other religions, Islam uses jihad as the last option either in self- defence, or territorial expansion. Jihad may mean self-purification in theory, but for political Islam, it is a strategy to defeat the enemies of Islam through full armed confrontation. While some people are defending Islam as a religion of peace, global political Islam has adopted jihad as a platform for military confrontation with the enemies of Islam. The international community is facing a tough time in combating the militant agenda of political Islam.
\end{abstract}

Keywords: jihad, religion, Islam, territorial expansion, political Islam, warfare in Islam

\section{Introduction}

'Islam' is derived from the Arabic word aslam, which means submission, surrender, resignation and committing of oneself to the cause of Allah (Cowan, 1968: 424, 426). Another Arabic word that is the root word of aslam is salam, which is interpreted as safety, immunity, freedom, soundness, well being, peacefulness, salutation or imperfection (Lane, 1978: 1415). The social and spiritual goal of Islam involves the attainment of peace through absolute submission to the will of Allah. A. R. I. Doi writes: "Islam means absolute submission to the creator and Lord. A Muslim is a believer whose faith (Iman) is firm in him and believes in the absolute unity of God who watches all his activities. The entire message of Islam, therefore, is based on two fundamentals; faith (Iman) and right doing (Ihsan)" (1981: 44).

A Muslim is not an ordinary citizen in any society. As a bearer and reservoir of peace, a faithful Muslim is called khalifat Allah (vice-gerent of Allah). As ambassador of Allah on earth, Muslims have a duty to promote peaceful co-existence in all human societies. Abul'ala Maududi writes: "The moral life of a Muslim will always be filled with godliness, piety, righteousness and truthfulness... He will never be a party to oppression or violation of human life and honour" (1960: 16). Although Islam is not a religion of violence, a good Muslim cannot condone evil in any form. In Islamic world-view, ungodly actions are tantamount to blatant violation of the divine order and disregard of the cosmic sovereignty of Allah.

Since God is far greater than any individual, a good Muslim must constantly protect the interest of Allah from irresponsible violation by infidels. Maududi comment more on the moral obligations of a Muslim as the conscience of society: "How can humiliation ever visit a person who is not prepared to bow his head or even spread his hand for any favour before anyone except God... He will be the most powerful and effective" (1960:17, 18). A good Muslim cannot allow injustice and ungodliness to prevail around him and he cannot yield to any form of intimidation. As an embodiment of truth, goodness and nobility, a Muslim should be undaunted by the tempests of adversity even at the cost of his life. Maududi writes: "If you understand the true character of a Muslim, you will be convinced that he cannot live in humiliation, abasement, or subjugation. He is bound to prevail and no power on earth can overwhelm him or subdue him" $(1960: 18,19)$.

\section{Islam as a Universalistic Religion}

From the very beginning, Islam laid claims to a divine mandate to convert humanity. Islam does not accept the principles of religious freedom as embodied in international documents. It does not recognize the individual rights of citizens to exercise an option either to embrace, or reject any religion. Submission to the will of Allah is not optional, it is mandatory. The non-believer is called Kafr (concealer). This is a person who has refused 
to exercise his faculties of reason, intellect, and intuition to recognize Allah, but rather abuse; his freedom of choice by choosing to deny his existence and supremacy. In Islamic reasoning, the unbeliever, or atheist suffers acute psychic malfunction, which blurs his vision and befogs the intellect. Atheism is therefore a state of abnormality. Unbelief is also seen as the worst category of ignorance. No ignorance can be greater than the rejection of one's creator and living on earth in opposition to him.

Islam has also interpreted unbelief as tyranny. Tyranny here means cruel and unjust application of force or power on an innocent person. Since Allah is the creator and owner of the universe, it is obligatory for human beings to worship him. It follows that it is a clear case of injustice, tyranny and cruelty for any body to enjoy God's benevolence without submitting to his will. Refusal to worship Allah is interpreted as ingratitude, infidelity and senseless rebellion. The argument within Islam is that human beings are not independent of God and cannot be allowed to live on earth in opposition to him. Maududi has this to say on the implication of unbelief in Islamic reasoning: "If an officer becomes disloyal to the state you dub him as traitor and renegade. If a person cheats his benefactor you have no hesitation in condemning him as ingrate... All that a man has and all that he uses for the benefit of others is a bestowal of God" (1960:9).

Unbelief is also viewed as a wanton and provocative violation of the rights of God. While Western Christianity is preoccupied with strategies to check global human rights violation, Islam has always defended the rights of God. The first right of God is the demand that all persons should put their faith and trust in God. The second right of God is the instruction that everybody must accept the leadership and guidance of God in all issues of life. The third right of God requires implicit and total obedience to his will and command. The fourth right of God is man's obligation to worship God (Maududi, 1960:155). The task of defending the rights of God cannot be successful without application of force, at least to compel obedience. This is the only reason why Islam has institutionalized warfare as a religious obligation. The Muslim is called a Mujahidun (warrior or soldier of Islam). Since in a collective sense, the ummah is the representative of Allah on earth, it is a breach of trust for Muslims to sit back and watch infidels violate the rights of God with impunity. It is at this juncture that we shall consider the concept of jihad in Islam.

\section{What Is Jihad?}

Jihad is derived from the Arabic word Jahada, which means "he strove or exerted himself against anything which is evil" (Doi, Hadith 1981:74). Doi has also contended that the etymology of jihad does not connote "... resorting to the use of swords and the shedding of blood to achieve it" (1981:74). Jihad is a holy war waged in self-defense against all forms of ungodliness, oppression, inhumanity, tyranny and dictatorship. Doi writes further: “... to raise one's voice against manifest wrong is one of the foremost duties of a Muslim, and particularly so when the wrongdoer is the established authority....to speak up for the truth even to the tyrant ruler, in which apparently there is, danger of losing one's life is the best jihad" (1981:74).

Prophet Muhammad divided jihad into two main categories; the major jihad, which is jihad against oneself, and the minor jihad, which is war against enemies of Islam. The major jihad, which is internal spiritual cleansing, self-denial, mortification, suppression and psychic annihilation of man's lower nature and sinful instinct, is more relevant than the minor jihad. The declaration of minor jihad means collective armed violence against enemies of Islam. In Arabic, the word jihad means "struggle". It is a struggle againstunbelief and moral struggle against sin and weakness of the flesh (Murk, 2006:137). Muhammad taught that jihad was a struggle in the cause of Allah against the world. Jim Murk has cited some of the utterances of Muhammad recorded in the Hadith. When Prophet Muhammad was asked 'what was the best deed'? The answer was “'To believe in Allah and his Apostle'. Then he added that the next best way was to participate in jihad in Allah's cause (Hadith, 1.25). He said, 'Paradise is under the shades of swords'. And the scimitar or curved sword is still one of the symbols of Islam" (2006:137).

Holy war is endorsed both in the Quran and in the Hadith. The clauses on jihad can be identified largely from the parts of the Quran that were written in the Medina period from 623 to 632. Jihad is commanded against infidels in over 120 verses of the Quran. We shall now present few verbatim quotations from the Quran on jihad:

Prescribed for you is fighting (against the unbelievers), although it be hateful to you. Yet it is possible that you will hate a thing, which is better for you... (Baidawi on Surah 2:216f).

Fight them on, until there is no more tumult, seduction, or oppression, and there prevail justice, faith in Allah, and the religion becomes Islam (Surah 2:193).

Kill the infidels, God will torment and cover them with shame (Surah 9:14). 
The ultimate purpose of jihad is to ensure that the entire world is converted to Islam, and universal jurisdiction of Shariah is actualized at all cost. Non- Muslims are potential targets in the armed struggle. Jihad requires a pledge of life and the courage to fight even to the point of death and if the warrior should pay the supreme price during the struggle there is an eternal reward on the day of resurrection. This is clearly stated in the Hadith:

The person who participates in Allah's cause.... Will be recompensed by Allah either with reward or booty or will be admitted to paradise (Hadith 9:4).

Wherever you find infidels kill them; for whoever kills them shall have reward on the Day of Resurrection (Hadith 9:4).

Good Muslims are expected to display maximum courage in fighting non-Muslims. They are expected to deal ruthlessly with infidels. "Prophet, make war on the infidels and the hypocrites and deal rigorously with them" (Surah 9:73). "Muhammad is Allah's prophet. Those who follow him are ruthless to the infidels" (Surah 48:29). "No umma (a member of Muslim community) should be killed for killing a kafir (an infidel).... Whoever changes his Islamic religion, kill him"(Hadith 9:50, 57). While few Muslim scholars are bent on denying the confrontational and bloody dimension of jihad, other's have said the truth. The distinguish Islamic philosopher and historian of the $14^{\text {th }}$ century, Ibn Khaldun (1332-1406) had said:

In the Muslim community, the holy war is a religious duty, because of the universalism of the Muslim mission and the obligation to convert everybody to Islam either by persuasion or force. The other religious groups (Christianity and Judaism) did not have universal mission, and the holy war was not a religious duty to them, save only for purposes of defense (qtd. in Murk, 2006:138).

The late Iranian spiritual leader Ayatollah Khomeini said the truth when he declared that, "Islam makes it incumbent on all adult males to prepare themselves for the conquest of countries so that the writ of Islam is obeyed in every country in the world" (qtd. in Murk, 2006:139). Hammudah Abdalati in his Islam in Focus admitted that there is a full Quranic approval for armed struggle against enemies of Islam: "Islam has recognized war as a lawful and justifiable course for self- defense and restoration of justice, freedom and peace" (1975:142).

\section{Islam as a Political Religion}

What is the correlation between politics and religion? It was Aristotle who said, "Man is a political animal" (qtd. in Copleston 1962:92). Man as politikos bios is naturally inclined to city-life and participation in activities aimed at acquisition of political power. Political power can be acquired either through peaceful means, or by imposition of superior military might. Political power here can be defined as man's overbearing influence, and control over his fellow man, the capacity to act, prevail and the courage to control the destiny of society, for good or bad. While man because of the need for governance, peace and security is homo politicus, he is at the same time, homo religiosus. Religion, more than politics is the primary determinant of social behaviour and action. Religion provides authentic and time-honoured standards upon which institutional norms can be evaluated. The spiritual and transcendental aspiration of man can only be resolved through religion.

Politics in Islam is not a dirty game rather it is a sacred trust. Muslims are not expected to allow a non-believer to rule over them. Such a thing is seen as an abomination, hence a terrible evil, which every Muslim must fight against, even to the supreme price of martyrdom. In Islam it is wise to die in opposition to evil, than to live in defeat and humiliation. Even though Jihad is a religious obligation, there is a political dimension. Whenever the tenets of Islam are violated or ignored with impunity, it is the duty of the umma to mobilize and disarm the enemies and impose Islam by force. Islamic concept of society is interpreted in a fundamental doctrinal dualism. The human society is geo-religiously divided into two: Dar al-Islam, meaning, abode of Islam or abode of peace, and Dar al-harb, meaning, enemy territory, abode of war, or land of unbelief. It is the religious duty of Muslim rulers to wage holy war (by all permissible and practical means), against the enemy territory. The goal of the incessant combat attack is to compel conversion into Islam. Jihad is a condition of permanent warfare. Even when military hostilities are suspended for overriding strategic and logistic considerations, jihad must continue through psychological and political means (Smaldone, 1977:69).

As a prelude to full scale armed confrontation, Muslim rulers are enjoined to apply persuasion as the first step to win the non-believers. It is obligatory for Dar al-Islam to negotiate with Dar al-harb. Political negotiation and concessions should aim at peaceful co-existence. It must be pointed out that the 
involvement of the ummah in such dialogue is only possible when victory against the enemy is in sight. Muslims are not likely to accept anything less than Dar al-harb being transformed into Dar al-Islam. As representatives of Allah in the negotiation table, the ummah cannot afford to betray the creator to please infidels. Negotiation is only a forum to persuade the enemy, explain the Islamic viewpoints, and then intimate the infidels on the consequences of disobedience.

Another option given to the non-Muslim is the status of dhimi(meaning tolerated non- Muslim). It entails unconditional loyalty and political submission to a Moslem government. The tolerated non-Muslims are disenfranchised, without citizenship rights. Cragg comments on the plight of Christians in Dar al-Islam: "Traditional tolerance allowed only a freedom to remain, to teach the faith only within the family, so that adherence become a circumstance of birth and continuity that of a closed community. There was no freedom to express faith, still less to recruit to it, outside that circle of one's origin" (1985:205). If persuasion fails, and the option of dhimi is rejected by the non-Muslim, the ummah is left with no alternative than to defend the rights of God through armed confrontation. The primary purpose of the minor jihad according to Omah Jah is: “... to spread the teachings of Islam by calling all human beings to the will of Allah and, therefore conduct their socio-economic and spiritual life according to the teachings of Allah (1993:180).

Even though jihad is a sacred obligation, Islam does not permit preemptive and unreasonable invasion of the enemy territory. There are acceptable conditions that should warrant the waging of jihad. According to Usman Dan Fodio, holy war (jihad) became obligatory under three conditions "Firstly on the orders of the Muslim ruler, secondly, if the enemy launches sudden counter-attack on Muslim territory... Thirdly, to rescue captured Muslims from the hands of the heathen" (Crowder 1962:73). Writing in the same vein, Joseph Smaldone gave additional conditions and justifications for jihad:

... holy war was obligatory in defense of the frontiers (ribat) and against polytheists or pagans; against apostates; against dissenters; against deserters and high way robbers; and against Scripturaries (that is Christians and Jews). It was a war against non-believers as well as Muslims who dissented or apostatized (1977:70).

Islam does not accept change of religion. Muslims do not have any reason to abandon their religion. A synthesis of the views of Fodio and Smaldone shows that Islam has endorsed warfare as a religious obligation. Jihad, both in the offensive and defensive dimensions, is aimed at eliminate contending religions, and consolidation of Islam.

\section{Jihad as Instrument for Territorial Expansion}

Historically, Islam has always used jihad as the principal instrument for territorial expansion. Ali Mazrui has observed that African Islam is in pursuit of comprehensive religion with the twin goals of expansionism and revivalism:

Expansion is about the spread of religion and its scale of new conversions. Revivalism is about the rebirth of faith among those who are already converted. Expansion is a matter of geography and population in search of new worlds to conquer. Revivalism is a matter of history and nostalgia in search of ancient worlds to re-enact (1993:247).

Territorial expansion is an aspect of the political functions of Islam. Islam anticipates a theocratic society on earth. There is no separation in issue of religion and politics. Commenting on the holistic nature of the Islamic faith Lateef Adegbite described Islam as: “... the religion (that) regulates not only matters of spiritual salvation and moral development but also economic and mundane affairs, as well as socio-political life, which other religions treat as temporal and therefore distinct from the spiritual" (1974:106,107). The ambition to expand ones territory cannot be achieved through peaceful means all the time, there are situations where maximum force must be applied to achieve victory. That is the relevance of jihad. Non-believers may not always yield to persuasion. Ogbu Kalu writes:

The jihads and other movements of reform within Islam pursued the ultimate goal of establishing a theocracy, a society and state ruled according to Islamic laws. Islam claimed total control over all aspects of life of its adherents both as individuals and as groups. Religion, it insists, must regulate not only matters of spiritual salvation and moral development, but also the socio-political economic affairs (1980:311).

\section{Conclusion/ Recommendation}

In view of the fact that Islam is a religion of peace and total submission to the will of Allah, Muslims should take 
decisive action to redeem the religion from the relics of its medieval origins. The goal of world conquest and forceful elimination of other religions should be rejected in the $21^{\text {st }}$ century. Islamic scholars should show sincerity in their apologetics by upholding their religion and also at the same time defending the truth. Deliberate concealment of truth does not save any useful purpose. Contemporary Islam should not be preoccupied with warfare and conquest. The transcendent and spiritual dimensions should dominate global Islamic discourse. The world is in dire need of peace and there is a clarion call for Muslims to have a rethink on minor jihad.

Islam has contributed immensely to the cultural, educational and spiritual upliftment of humanity. Islam has come of age, and there are urgent reasons for fundamental reforms that will accommodate the peculiar existential interests and priorities of modern man. The ulama should bolt out of the mystical cocoon and start a new era in social analysis and ratiocination aimed at updating Islamic theology, jurisprudence and philosophy. It is strongly recommended that the ummah should put functional machinery in motion that will lead to a consensus to abolish minor jihad. The gains of the minor jihad, which include looting, killing one's enemies, sharing of booties and territorial expansion should now appear detestable to all men of conscience. Muslims should join the global struggle for the recognition and observance of religious freedom. It is recommended that Islamic jurisprudence should integrate United Nation conventions on international humanitarian law and human rights into the Islamic corpus juris. Islam cannot continue to ignore the laws of war and fundamental human rights in the $21^{\text {st }}$ century.

\section{References}

Abdalati, H. (1975). Islam in Focus. American Trust Publications.

Adegbite, L. (1974). The Islamic Way of Nation Building. Orita, Ibadan Journal of Religious Studies, 8, 40-51.

Al Faruqi. Isma'il. (1979). Islam. Illinois: Argus.

Ayandele, E. (1966). External Influence on Africa Society. In J. Anene, \& G. Brown (Eds.), Africa in Nineteenth and Twentieth Centuries. Ibadan: Nelson.

Caner, M. E., \& Caner, E. F. (2002). Unveiling Islam. Kaduna: Evangel.

Cooper, A., \& Maxwell, E. A. (Eds.). (2003). Ishmael My Brother. Kaduna: Evangel.

Copleston, F. (1962). A History of Philosophy. New York: Image.

Cowan, J. M. (1968). A Dictionary of Modern Written Arabic. Wiesbaden: Marrassowitz.

Cragg, K. (1985). The Call of the Minaret. Mary Knoll, New York: Orbis.

Crowder, M. (1962). The Story of Nigeria. London: Faber.

Doi, A. R. I. (1981). Introduction to the Hadith. Zaria: Hudahuda.

Jah, O. (1993). The Impact of Jihad on the Senegambian Society. In Nural et al. (Eds.), Islam Africa: Proceedings of the Islam in Africa Conference (pp. 179-186). Ibadan: Spectrum.

Kalu, O. U. (1980). Religion as a Factor in National Development. In E. C. Amucheazi (Ed.), Readings in Social Sciences: Issues in National Development (pp. 307-319). Enugu: Fourth Dimension.

Lane, E. W. (1978). Arabic-English Lexicon (Bkl, part 4). Lahore: Islamic Book Center.

Maududi, A. (1960). Toward Understanding of Islam. Riyadh: WAMY.

Mazrui, A. A. (1993). African Islam and Comprehensive Religion: Between Revivalism and Expansion. In Nura et al. (Eds.), Islam in Africa: Proceedings of Islam Africa Conference (pp. 247-265). Ibadan: Spectrum.

Murk, J. (2006). Islam Rising. Springfield, MO: 21 st Century Press.

Smaldone, J. P. (1977). Warfare in the Sokoto Caliphate: Historical and Sociological Perspectives. Cambridge University Press. http://dx.doi.org/10.1017/CBO9780511759536

Trimingham, J. S. (1949). Islam in Sudan. London: Oxford University Press. 